\title{
Relationship between corpora lutea or fetal number and plasma concentrations of progesterone and testosterone in mice
}

\author{
Elizabeth M. Humphreys, Rita Ghione, R. G. Gosden, B. M. Hobson* \\ and L. Wide† \\ Department of Physiology, University Medical School, Teviot Place, Edinburgh EH8 9AG, U.K.; \\ * Department of Obstetrics and Gynaecology, 37 Chalmers Street, Edinburgh EH3 9EW, U.K.; and \\ $\dagger$ Department of Clinical Chemistry, University of Uppsala, Sweden
}

\begin{abstract}
Summary. Blastocysts (1-14) were transferred unilaterally into 63 pseudopregnant mice which were killed on Day 17. Plasma progesterone concentrations were significantly $(P<0.05)$ lower in animals with one fetus than in those with $2-5$ or 9-14 fetuses. Plasma testosterone concentrations were correlated with fetal number in mice with 1-13 fetuses $(P<0.001)$. The total placental content of chorionic gonadotrophin in 13 litters varied directly with the number in the litter (1-6), and was $1.67 \pm 0 \cdot 15 \mathrm{ng} /$ placenta. The number of corpora lutea per mouse was negatively correlated with mean CL volume per mouse $(P<0.001)$, and the number of conceptuses was positively correlated with mean $C L$ volume per mouse $(P<0.001)$. The effect of conceptuses on the ovary was systemic. The relationship between plasma testosterone concentration and conceptus number may be due to gonadotrophins acting on the ovary, or androgens produced by the placenta or fetus.
\end{abstract}

\section{Introduction}

The mouse placenta contains a gonadotrophin similar to human chorionic gonadotrophin (hCG) (Wide \& Hobson, 1977, 1978; Wide, Hobson \& Wide, 1980; Rao, Pointis \& Cedard, 1982). Placental CG reaches peak levels on Days 11 and 16 post coitum (Wide \& Wide, 1979), and may be partly or wholly responsible for maintaining the secretion of ovarian steroids during the second half of pregnancy, when the continuation of gestation is not dependent on the presence of the pituitary (Newton \& Beck, 1939).

A quantitative relationship might exist between the number of implantations and the production of ovarian steroids, but the evidence for this is contradictory in both the mouse and the rat. Plasma progesterone and testosterone concentrations increase in the second half of pregnancy in the mouse, and plasma progesterone values are greater in mice selected for large litters than for small (Michael, Geschwind, Bradford \& Stabenfeldt, 1975; Barkley, Michael, Geschwind \& Bradford, 1977). In experiments using $\mathrm{C} 3 \mathrm{H}$ mice in which the number of fetuses was experimentally adjusted to between 1 and 10 , serum concentrations of progesterone were directly proportional to litter size (Soares \& Talamantes, 1983). However, neither the number of corpora lutea nor that of fetuses is correlated with plasma progesterone concentrations in Rockland Swiss mouse litters varying in size from 7 to 11 (Simon, Bridges \& Gandelman, 1978). In the rat there is a significant correlation between total corpus luteum weight and serum progesterone concentration on Day 16 of pregnancy, but reducing the number of conceptuses from 12 to 5 does not significantly alter the levels of progesterone (Elbaum, Bender, Brown \& Keyes, 1975). However, Kato, Morishige \& 
Rothchild (1979) found a direct relationship between the number of conceptuses and serum progesterone concentration in rats on Day 15 of pregnancy.

Our experiments were designed to test whether the number of fetuses is related to plasma concentrations of testosterone and progesterone in mice, by independently controlling the numbers of fetuses and corpora lutea by using embryo transfer. This design also enabled us to examine whether fetuses exert a local trophic effect on the ipsilateral ovary, as has been found in rats carrying one or two experimentally implanted fetuses on Day 18 of pregnancy (Zambrana \& Greenwald, 1971).

\section{Materials and Methods}

The mice were from our own closed colony of randomly bred albinos, maintained under a constant schedule of $14 \mathrm{~h}$ light and $10 \mathrm{~h}$ dark. Food and water were freely available.

Fetal number was controlled by transferring blastocysts obtained from donor mice on Day 4 post coitum to hosts on the 3 rd day after mating with vasectomized males. Donor mice were prepared for superovulation by i.p. injections of 5 i.u. PMSG and 5 i.u. hCG $48 \mathrm{~h}$ apart. Animals were then paired with males of proven fertility, and inspected for a coital plug the following morning (Day 1 of pregnancy). Blastocysts were flushed from the uterine horns into sterile Petri dishes using Medium 199 (Flow Laboratories, Irvine, U.K.) containing 20 mM-Hepes buffer, $10 \%$ fetal calf serum and 100 units penicillin-G/ml (Sigma, London, U.K.). Host animals were anaesthetized with 2,2,2-tribromethanol (Avertin: Winthrop, Surbiton upon Thames, U.K.), on the 3rd day after a sterile mating with a vasectomized male, and the uterus was exposed via a flank incision. Between 1 and 18 embryos were collected in a small volume of medium $(<1 \mu \mathrm{l})$, in an orally controlled pipette, and injected unilaterally into one uterine horn per animal, choosing alternate sides in successive mice.

The mice were anaesthetized on Day 17 of pregnancy with an injection of amylobarbitone sodium. The thorax was opened and the mouse exsanguinated via the heart. The blood was placed in heparinized tubes, centrifuged and the plasma kept for the radioimmunoassay (RIA) of progesterone and testosterone.

The number of implantation sites and fetuses was counted, and placentae and fetuses were weighed. The maternal ovaries were weighed after fixation for $24 \mathrm{~h}$ in Bouin's fluid. The ovaries from 14 mice with 1 fetus, 15 with 2-5 fetuses, 5 with 6-8 fetuses and 11 with 9-14 fetuses were cut at $10 \mu \mathrm{m}$ and stained with haematoxylin and eosin. The number of corpora lutea in each ovary was counted, and their volumes measured by the method of Rowlands (1961).

Plasma from 62 mice was assayed for progesterone by the method of Scaramuzzi, Corker, Young \& Baird (1975). Two $50 \mu$ l aliquants from the plasma of each animal were extracted with $2 \mathrm{ml}$ petroleum ether (Analar reagent grade). The ether was evaporated to dryness under nitrogen and the residue dissolved in $1 \mathrm{ml}$ phosphate buffer. Duplicate $0.1 \mathrm{ml}$ portions of the extract were assayed with a specific RIA using sheep anti-progesterone antiserum $91929 / 9$ as described by Scaramuzzi et al. (1975). There was little or no cross-reaction between this antiserum and androstenedione, cortisol, pregnenolone, testosterone, or 17-hydroxyprogesterone. There was a significant cross-reaction with progesterone, $11 \alpha$ - and $11 \beta$-hydroxyprogesterone and 11ketoprogesterone.

Testosterone was assayed in plasma from 26 mice, with litters of $1-13$, by the method of Collins, Mansfield, Alladina \& Sommerville (1972). The testosterone antiserum (NEA-042B; New England Nuclear, Boston, MA, U.S.A.) was from a rabbit immunized with a testosterone-3-CMO-bovine serum albumin conjugate. Cross-reactivity at $50 \%$ displacement was about $50 \%$ for dihydrotestosterone and was negligible for other androgens, progesterones or oestrogens. The efficiency of the extraction method was $85 \%$ (range $75-94 \%$ ). The intra-assay variation was $4.8 \%$ and the inter-assay variation about $9 \%$. The detection limit was $0.05 \mathrm{nmol} / 1$. 


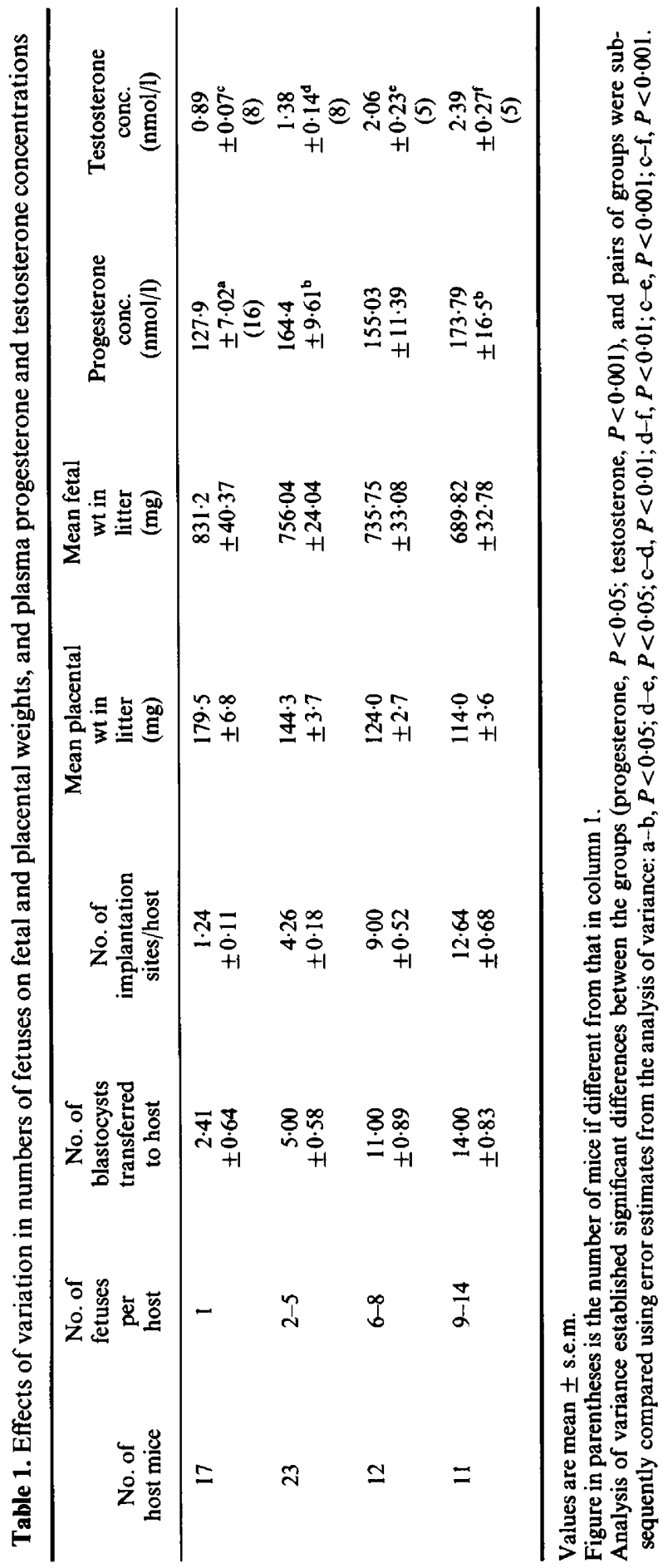


Placentae from 13 mice with litters of $1-6$ were homogenized in ice-cold acetone $(5 \mathrm{ml} / \mathrm{g})$ plus ice-cold ether $(1 \mathrm{ml} / \mathrm{g})$ and the tissue extracts were kept at $+4^{\circ} \mathrm{C}$ overnight and centrifuged. The tissue residue was washed with acetone plus ether, air dried at room temperature and kept at $-20^{\circ} \mathrm{C}$ until analysed. The acetone-ether precipitates were then dissolved in saline $(9 \mathrm{~g} \mathrm{NaCl} / \mathrm{l})$, left overnight at $+4^{\circ} \mathrm{C}$ and centrifuged. The saline extracts were then assayed by a solid-phase RIA (Wide, 1969). The reagents were ${ }^{125} \mathrm{I}$-labelled $\mathrm{hCG}$ and a rabbit hCG-antiserum coupled to CNBr-activated Sephadex. The samples were incubated with the solid phase-coupled antibodies for 6 days at room temperature and subsequently for 1 day with addition of labelled antigen. The unknown samples were tested in 5 or 6 concentrations with a log dose interval of 0.301 and in duplicates at each dose. A highly purified preparation of hCG was used as a standard: I ng hCG corresponded to 5 arbitrary units $\left(\mathrm{U}_{\mathrm{arb}}\right)$ of mouse $\mathrm{CG}$ (Wide \& Wide, 1979).

\section{Results}

The weight of ovaries on the implantation side of the 63 mice was $9.48 \pm 0.27 \mathrm{mg}$ (mean \pm s.e.m.), and on the contralateral side $8.77 \pm 0.24 \mathrm{mg}$ (paired $t=-1.8 ; P>0.05$ ). There was no significant difference between the mean volumes of corpora lutea $(\mathrm{CL})$ in ovaries on the implantation side $\left(0.350 \pm 0.79 \mathrm{~mm}^{3}\right)$, and those of $\mathrm{CL}$ in the other ovary $\left(0.354 \pm 0.008 \mathrm{~mm}^{3}\right.$; paired $t=0.692$; $P>0.4)$. There was no correlation between the combined weights of both ovaries and fetal number (intercept $=17 \cdot 65 ;$ slope $=0 \cdot 13 ; r=0 \cdot 19 ; P>0 \cdot 1$ ). The fetal and placental weights (Table 1 ) were within the normal range for our colony of mice.

There was no correlation between the number of $\mathrm{CL} /$ mouse and plasma progesterone concentrations (Text-fig. 1a). Analysis of variance showed that the concentration of plasma progesterone in mice with 1 fetus was significantly less than that in mice with $2-5$ and 9-14 fetuses

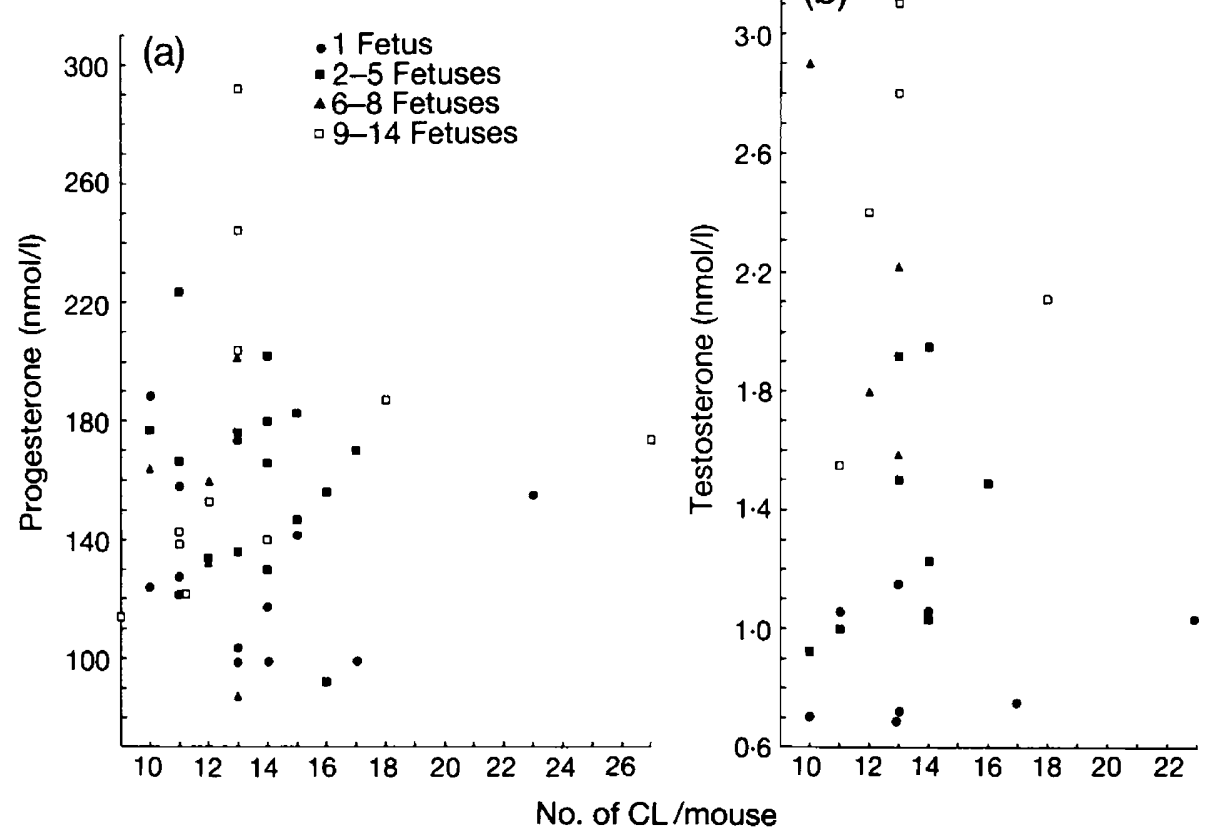

Text-fig. 1. The relationship between plasma concentrations of (a) progesterone and (b) testosterone and the number of corpora lutea in the pregnant mouse. In (a) intercept $=142.9$, slope $=0.84, r=0.07, P>0.6$, and in (b) intercept $=1.47$, slope $=0, r=-0.01, P>0.9$. 


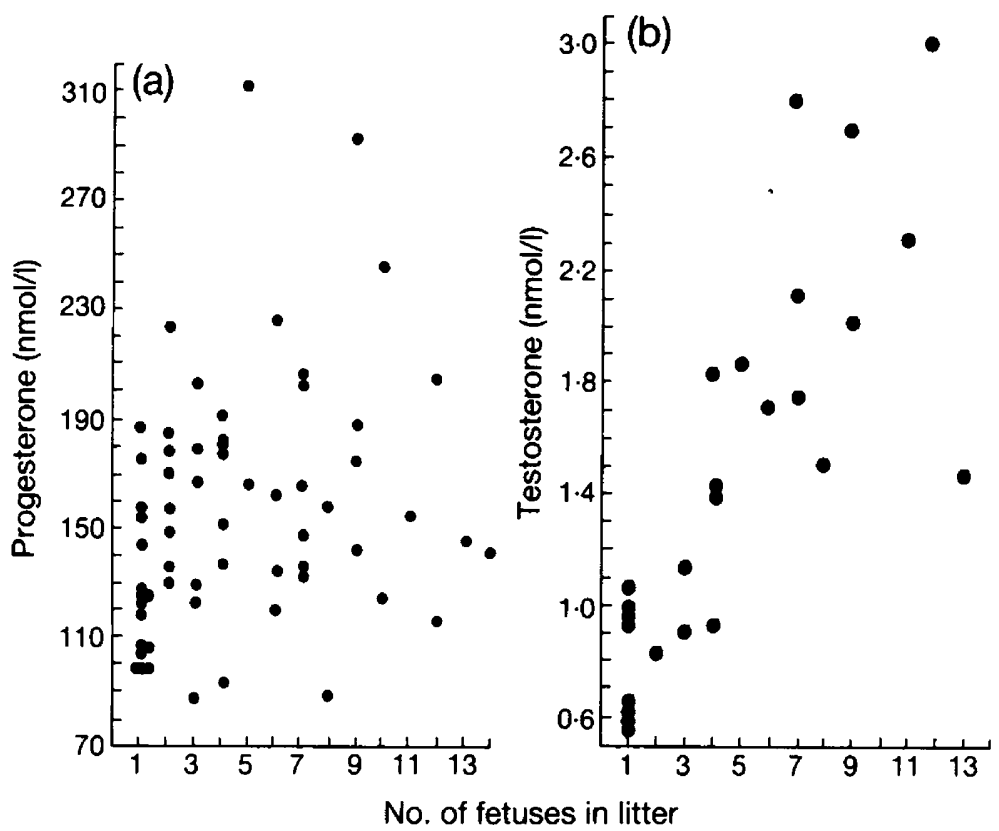

Text-fig. 2. The relationship between plasma concentrations of (a) progesterone and (b) testosterone and the number of fetuses in the litter in the mouse. In (b) intercept $=0.84$, slope $=0.15, r=0.78, P<0.001$.

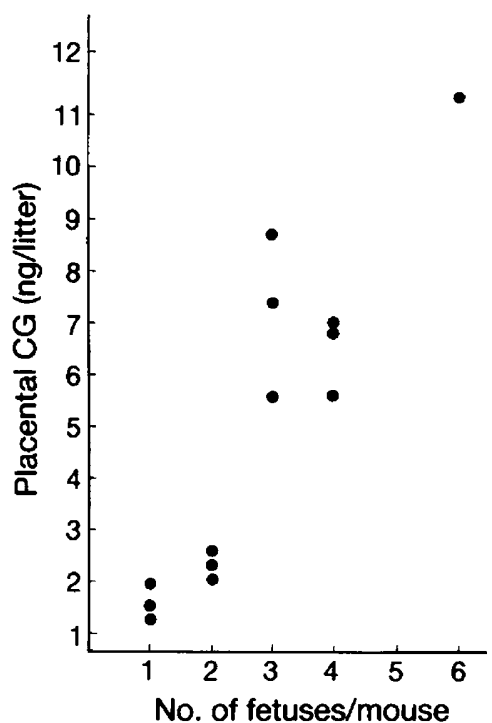

Text-fig. 3. The relationship between placental CG content/litter and number of fetuses per mouse. Intercept $=0.58$, slope $=1.96, r=0.90, P<0.001$.

(Table 1; Text-fig. 2a). There was no correlation between the number of $\mathrm{CL} /$ mouse and plasma testosterone concentrations (Text-fig. 1b) but the correlation between plasma testosterone values and fetal number was significant (Table 1; Text-fig. 2b). The mean chorionic gonadotrophin content was $1.67 \pm 0.15 \mathrm{ng} /$ placenta, equivalent to $8.35 \mathrm{U}_{\mathrm{arb}}$ mouse $C G$ (Wide \& Wide, 1979). The 
total amount of chorionic gonadotrophin in all placentae in each of the 13 litters varied directly with the number present (range 1-6) (Text-fig. 3), but the placental CG value was not related to the plasma progesterone concentration in these 13 mice (intercept $=134.46$; slope $=2.33 ; r=0.24$; $P>0 \cdot 4)$.

To see whether there was any effect of the total number of $\mathrm{CL} /$ mouse, or of conceptuses on the mean $\mathrm{CL}$ volume/mouse, a multiple regression was done using the data shown in Text-fig. 4 . The

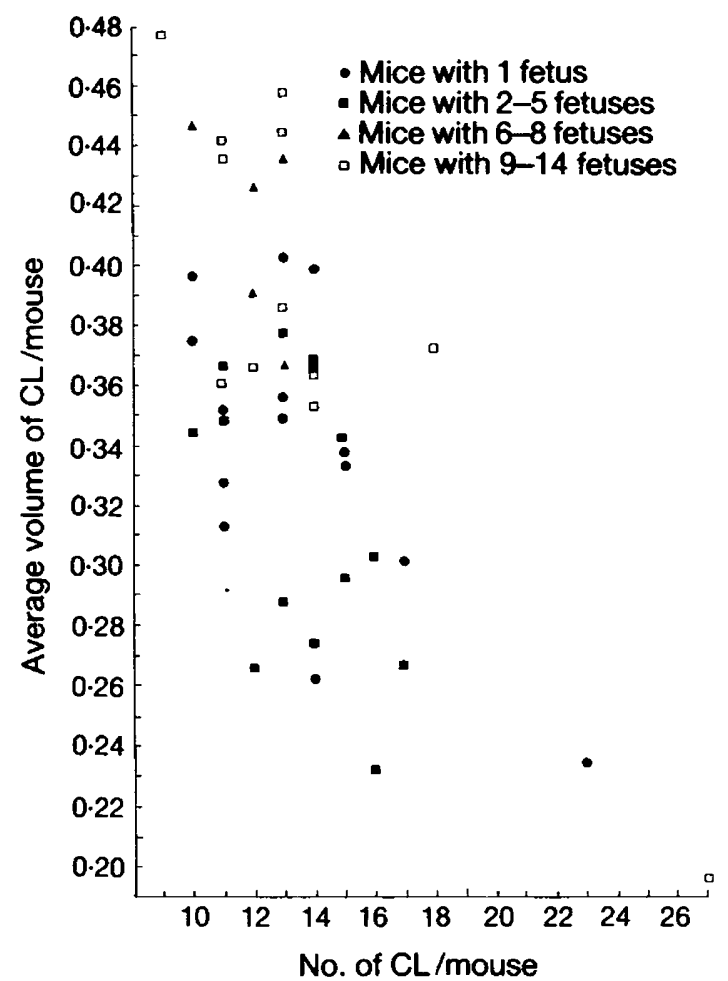

Text-fig. 4. The relationship between the average volume of corpora lutea per mouse and the number of corpora lutea per mouse.

Table 2. Multiple regression analysis showing the effect of the number of corpora lutea/mouse, and of the number of conceptuses on the mean volume of the corpora lutea/mouse $\left(\mathrm{mm}^{3}\right)(y)$

\begin{tabular}{lccc}
\hline Term & Estimate & Standard error & Significance \\
\hline $\begin{array}{l}\text { Intercept of line } \\
\text { on } y \text { axis }\end{array}$ & 0.47765 & & \\
$\begin{array}{l}\text { Effect of number of } \\
\text { fetuses (partial } \\
\text { regression coefficient } b_{1} \text { ) }\end{array}$ & 0.00726 & 0.00152 & $P<0.001$ \\
$\begin{array}{l}\text { Effect of no. of } \mathrm{CL} / \text { mouse } \\
(\text { partial regression } \\
\text { coefficient } b_{2} \text { ) }\end{array}$ & -0.01175 & 0.00187 & $P<0.001$ \\
\hline
\end{tabular}




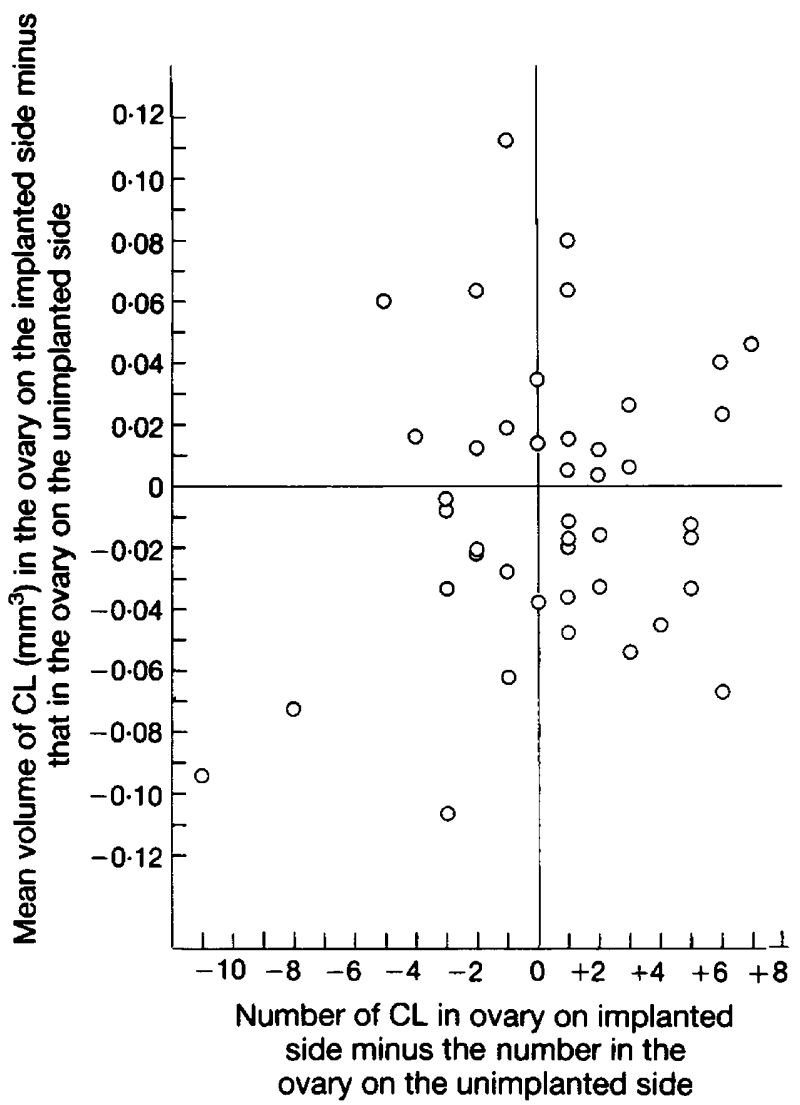

Text-fig. 5. The relationship between the number of corpora lutea and the mean volume of corpora lutea in each ovary of mice with unilateral implantations. Intercept $=-\mathbf{0 . 0 0 5 3}$, slope $=0.021, r=0.1747, P>0.2$.

results (Table 2) show that both factors have a small but significant correlation with mean CL volume/mouse. For example, in a mouse with 7 fetuses and $13 \mathrm{CL}$ we can predict that the mean volume of the $\mathrm{CL}$ would be $0.376 \mathrm{~mm}^{3}$. If the number of fetuses was increased by 1 the mean volume would be $0.383 \mathrm{~mm}^{3}$, an increase of $1.9 \%$. If, instead, the number of CL was increased to 14 , the mean volume would be reduced to $0.364 \mathrm{~mm}^{3}$, a decrease of $3 \cdot 1 \%$. The multiple regression analysis was repeated after the data from two mice with 23 and 27 CL (Text-fig. 4) had been excluded, since such large numbers are unusual. The significance levels were only marginally increased, and our conclusions are unaffected.

To see whether there was any correlation between the number and mean volume of $\mathrm{CL}$ in each individual ovary of the mouse we plotted the difference in the number of $\mathrm{CL}$ on the implanted and unimplanted sides against the corresponding differences in their mean volumes. There was no correlation (Text-fig. 5). There is no evidence that within each mouse the mean CL volume is less in the ovary with the greater number of CL than in the ovary with the smaller number.

\section{Discussion}

We have shown that concentrations of plasma progesterone on Day 17 of pregnancy are independent of fetal numbers in our strain of mice when more than 1 fetus is present. In this strain the 
gestation period is related to litter size: in 1246 dated mouse pregnancies $60 \%$ of litters with one fetus, but $<18 \%$ of those with 8 or more fetuses were born after the 20 th day of pregnancy (Dewar, 1968). Our results cannot exclude the possibility that a correlation between litter size and progesterone levels existed earlier in pregnancy. By Day 17 progesterone levels in mice with larger litters might have already declined. The period of functional activity of the mouse corpus luteum lasts from the 8 th to the 16th day of gestation, i.e. up to 3 days before parturition, and from the 18 th day the corpus luteum accumulates fat and gradually shrinks (Deanesly, 1930). Soares \& Talamantes (1983) showed that the level of serum progesterone correlated with litter size on Day 15 of pregnancy in $\mathrm{C} 3 \mathrm{H}$ mice in which fetuses were destroyed on Day 7 to adjust litter sizes to groups of 1-2, 3-4 or 8-10. However Simon et al. (1978), using Rockland Swiss mice, found that neither the numbers of corpora lutea nor fetuses correlated with levels of plasma progesterone on Day 15 of pregnancy. These differences may be due to the strains of mice used.

It has been suggested that the mouse placenta synthesizes progesterone during the second half of gestation, and that at least part of this progesterone is secreted into the maternal circulation, although the contribution of the placenta to overall progesterone concentration is very low compared with that of the ovary (Pointis, Rao, Latreille, Mignot \& Cedard, 1981). In the mouse, removal of the ovaries or corpora lutea leads to the termination of pregnancy (Parkes, 1928; Newton \& Lits, 1938). Progesterone and oestrogen are necessary for the maintenance of gestation (Robson, 1938a, b; Jaitly, Robson, Sullivan \& Wilson, 1966). Hypophysectomy after the 10th day does not interrupt pregnancy, and the trophic support of the ovary thereafter is dependent upon the presence of the placenta (Mirskaia, 1929; Selye, Collip \& Thomson, 1933; Newton \& Beck, 1939).

There are two placental hormones which may maintain the production of steroid by the ovary. Mouse placental lactogen is positively correlated with litter size (Markoff \& Talamantes, 1981) and may play a part in the maintenance of luteal cell LH receptors as has been suggested in the rat (Gibori \& Richards, 1978). The role of endogenous CG in the mouse is not known but in the rat the injection of hCG stimulates the production of both oestradiol and testosterone, although it has no effect on ovarian progesterone secretion. In vitro, hCG activates the enzymes involved in the conversion of progesterone to testosterone (Kalison \& Gibori, 1983).

We have shown that the amount of CG is related to the number of fetuses in the litter, and this is undoubtedly a function of total placental mass. The amount of CG per placenta in our strain of mice at Day 17 of gestation is similar to that found by Wide \& Wide (1979) in the NMRI strain. The amount of mouse $\mathrm{CG}$ is not related to the mean plasma progesterone concentration.

Both placental CG and plasma testosterone concentration increase with increasing litter size, and the CG may stimulate the production of testosterone by the mouse ovary. In the rat the ovaries secrete only a limited amount of testosterone in the second half of pregnancy, when the conceptuses become an important source of testosterone (Sridaran, Basuray \& Gibori, 1981), and a similar situation may exist in the mouse.

Bartholomeusz \& Bruce (1976) showed that mean corpus luteum weight per rat was negatively related to the number of corpora lutea per rat. We have shown the same for luteal volume in the mouse, and that there is a positive correlation between the number of conceptuses and mean CL volume, suggesting a trophic effect of the conceptuses on the corpora lutea.

In our mice there was no local effect of 1 or 2 fetuses on the weight of the ipsilateral ovary, as was found in the rat on Day 18 of pregnancy (Zambrana \& Greenwald, 1971), nor was there any unilateral effect of the number of fetuses on the volume of the corpora lutea. The effect of the conceptuses on the ovaries was therefore systemic.

We thank Dr R. J. Prescott for statistical advice, Mr Christer Bengtsson, Miss Margareta Hoffstedt and Mr I. A. Swanston for technical assistance. L.W. received financial support from the Swedish Medical Research Council (grant 637). 


\section{References}

Barkley, M.S., Michael, S.D., Geschwind, I.I. \& Bradford, G.E. (1977) Plasma testosterone during pregnancy in the mouse. Endocrinology 100, 1472-1475.

Bartholomeusz, R.K. \& Bruce, N.W. (1976) Effects of maternal progesterone supplementation on fetal, placental and corpus luteal weights in the rat. Biol. Reprod. 15, 84-89.

Collins, W.P., Mansfield, M.D., Alladina, N.S. \& Sommerville, I.F. (1972) Radioimmunoassay of plasma testosterone. J. Steroid Biochem. 3, 333-348.

Deanesly, R. (1930) The corpora lutea of the mouse, with special reference to fat accumulation during the oestrous cycle. Proc. R. Soc. B 106, 578-595.

Dewar, A.D. (1968) Litter size and the duration of pregnancy in mice. $Q$. Jl exp. Physiol. 53, 155-161.

Elbaum, D.J., Bender, E.M., Brown, J.M. \& Keyes, P. (1975) Serum progesterone in pregnant rats with ectopic or in situ corpora lutea: correlation between amount of luteal tissue and progesterone concentration. Biol. Reprod. 13, 541-545.

Gibori, G. \& Richards, J.S. (1978) Dissociation of two distinct luteotropic effects of prolactin: regulation of luteinizing hormone-receptor content and progesterone secretion during pregnancy. Endocrinology 102, 767-774.

Jaitly, K.D., Robson, J.M., Sullivan, F.M. \& Wilson, C. (1966) Hormonal requirements for the maintenance of gestation in hypophysectomized mice. J. Endocr. 34, iv-v, Abstr.

Kalison, B. \& Gibori, G. (1983) Role of prolactin in hCG stimulation of ovarian production of testosterone and estradiol in the rat. In Factors Regulating Ovarian Function, pp. 93-97. Eds G. S. Greenwald \& P. F. Terranova. Raven Press, New York.

Kato, H., Morishige, W.K. \& Rothchild, I. (1979) A quantitative relation between the experimentally determined number of conceptuses and corpus luteum activity in the pregnant rat. Endocrinology $105,846-850$.

Markof, E. \& Talamantes, F. (1981) Serum placental lactogen in mice in relation to day of gestation and number of conceptuses. Biol. Reprod. 24, 846-851.

Michael, S.D., Geschwind, I.I., Bradford, G.E. \& Stabenfeldt, G.H. (1975) Pregnancy in mice selected for small litter size. Reproductive hormone levels and effect of exogenous hormones. Biol. Reprod. 12, 400-407.

Mirskaia, L. (1929) On the presence of a kyogenic substance in the mouse placenta. Proc. R. Soc. Edinb. 50, 104-111.

Newton, W.H. \& Beck, N. (1939) Placental activity in the mouse in the absence of the pituitary gland. $J$. Endocr. 1, 65-75.

Newton, W.H. \& Lits, F.J. (1938) Criteria of placental endocrine activity in the mouse. Anat. Rec. 72, 333-345.

Parkes, A.S. (1928) The role of the corpus luteum in the maintenance of pregnancy. J. Physiol., Lond. 65, $341-349$.

Pointis, G., Rao, B., Latreille, M.T., Mignot, T.M. \& Cedard, L. (1981) Progesterone levels in the circulating blood of the ovarian and uterine veins during gestation in the mouse. Biol. Reprod. 24, 801-805.

Rao, B., Pointis, G. \& Cedard, L. (1982) Presence of a chorionic gonadotrophin-like factor in mouse placental cultures during the second half of gestation. J. Reprod. Fert. 66, 341-348.

Robson, J.M. (1983a) Quantitative data on the inhibition of oestrus by testosterone, progesterone and certain other compounds. J. Physiol., Lond. 92, 371-382.

Robson, J.M. (1983b) Mechanisms of oestrous inhibition in the mouse during pregnancy. Q. Jlexp. Physiol. 28, 195-205.

Rowlands, I.W. (1961) Effects of hysterectomy at different stages in the life cycle of the corpus luteum in the guinea pig. J. Reprod. Fert. 2, 341-350.

Scaramuzzi, R.J., Corker, C.S., Young, G. \& Baird, D.T. (1975) Production of antisera to steroid hormones in sheep. In Steroid Immunoassay, pp. 111-122. Eds E. H. D. Cameron, S. G. Hillier \& K. Griffiths. Alpha Omega Publishing, Cardiff.

Selye, H., Collip, J.B. \& Thomson, D.L. (1933) Effects of hypophysectomy upon pregnancy and lactation in mice. Proc. Soc. exp. Biol. Med. 31, 82-83.

Simon, N.G., Bridges, R.S. \& Gandelman, R. (1978) Plasma progesterone in Rockland-Swiss mice. Endokrinologie 72, 247-249.

Soares, M.J. \& Talamantes, F. (1983) Genetic and litter size effects on serum placental lactogen in the mouse. Biol Reprod. 29, 165-171.

Sridaran, R., Basuray, R. \& Gibori, G. (1981) Source and regulation of testosterone secretion in pregnant and pseudopregnant rats. Endocrinology 108, 855-861.

Wide, L. (1969) Radioimmunoassays employing immunosorbents. Acta endocr., Copenh., Suppl. 142, 207-221.

Wide, L. \& Hobson, B.M. (1977) Presence of chorionic gonadotrophin and free alpha- and beta-subunits in placental extracts of the rat, mouse and hamster. Acta endocr., Copenh., Suppl. 212, 31, Abstr.

Wide, L. \& Hobson, B.M. (1978) Chromatographic studies on a chorionic gonadotrophic activity in the placenta of the rat, mouse and hamster. Uppsala $J$. med. Sci. 83, 1-6.

Wide, L. \& Wide, M. (1979) Chorionic gonadotrophin in the mouse from implantation to term. J. Reprod. Fert. 57, 5-9.

Wide, L., Hobson, B.M. \& Wide, M. (1980) Chorionic gonadotrophin in rodents. In Chorionic Gonadotropin, pp. 37-51. Ed. S. J. Segal. Plenum Press, New York.

Zambrana, M.A. \& Greenwald, G.S. (1971) Effects of fetal, ovarian and placental weight of various number of fetuses in the rat. Biol. Reprod. 4, 216-223.

Received 31 July 1984 